\title{
ИСТОРИОГРАФИЯ ЛОКАЛИЗАЦИИ ТРЕХ ЦЕНТРОВ РУСОВ ВОСТОЧНЫХ АВТОРОВ
}

В статье произведен анализ историографии вопроса о трех центрах русов - Славии, Куябе и Арсании, сообщение о которых является одним из старейших рассказов восточных географов и представляет несомненную ценность дпя изучения раннего периода истории Древней Руси (IX-X вв.), и сделано заключение о ее современном состоянии. Этот рассказ встречается в арабо-персидской литературе на протяжении всего средневековья. Сообщения авторов X-XI вB. изучены достаточно хорошо, но при этом к их интерпретации остается ряд вопросов, связанных главным образом С неопределенностью сообщений, позволяющих разные толкования. Данные источников XII-XIV вв. менее известны, но при этом они представляют не меньшую ценность для историков. Вопрос локализации трех центров русов вызывает у ученых разногласия вот уже 200 лет. Исследователи предлагали самые разные версии. Главный вопрос при этом стоял в локализации Арсании третьего центра. Проблемами в локализации Арсании были скудность сведений, данных арабо-персидскими авторами, и крайне противоречивый характер сообщений об этом центре русов. В числе гипотез были южные локализации: на Таманском полуострове, в Крыму, на территории современной Украины, в Придунавье; северные: на Балтике, на верхней Волге; в Центральной России: в Рязани, в Среднем Поволжье. Ряд исследователей пытался доказать, что Арсания - не реальный географический объект, а фантом - миф, контаминация сведений о других областях или метафора. В последнее время исследователи вновь вернулись к классическим представлениям, позволяющим считать все три центра реальными географическими объектами. Среди появившихся недавно версий локализации Арсании в Галицко-Волынской Руси, в районе Смоленска, в Волго-Окском междуречье, в Приазовье, на Нижней Волге (в землях буртасов). Одна из последних и наиболее убедительная локализация помещает Арсанию в Нижнем Прикамье, а столицу Арсании - Арсу связывает с городищем Иднакар. Подтверждение ей дают не только письменные источники, но и данные археологии.

Ключевые слова: восточные источники, историография, три центра русов, Арса, Арсания, городище Иднакар, Солдырское городище.

\section{HISTORIOGRAPHY OF LOCALIZATION OF THREE CENTERS OF RUSES} OF EASTERN AUTHORS

The article analyzes the historiography of the question of the three centers of Ruses - Slavia, Kuyaba and Arsania, the report of which is one of the oldest stories of Eastern geographers and is of undoubted value for the study of the early period of the history of Ancient Russia (IX-X centuries), and concludes on its current state. This story is found in the Arab-Persian literature throughout the middle ages. The information provided by the authors of the $X-X \mid$ centuries have been studied fairly well but their interpretation leaves some ambiguity, mainly related to the uncertainty of communications allowing different interpretations. The data sources of the XII-XIV centuries are less known, but they are no less valuable for historians. The issue of localizing the three centers of Ruses has been considered controversial for 200 years. The researchers offered a variety of versions. The main question was in the localization of Arsania the third center. The challenges in localizing Arsania were the paucity of information, the data of the Arab-Persian authors, and extremely contradictory messages about the center of the Ruses. Among the hypotheses were the south-

Период в истории Древней Руси, заключенный между серединой IX в. и концом X в., представ- ern localization: on the Taman Peninsula, in the Crimea, on the territory of modern Ukraine, in the Danube; Northern: in the Baltic, on the upper Volga; in Central Russia: in Ryazan the middle Volga region. A number of researchers tried to prove that Arsania was not a real geographical object, but a phantom - a myth, a contamination of information about other areas or a metaphor. Recently, researchers have returned to the classical concepts; it allowed considering all three centers as real geographical objects. Among the recent versions of the localization of Arsania in Galicia-Volyn Russia, near Smolensk, in the Volga-Oka Mesopotamia, in the Azov region, on the Lower Volga (in the lands of Burtas). One of the last and most convincing localization places of Arsania is the Lower Kama region, and the capital of Arsania - Arsa is connected with the settlement of Idnakar It is confirmed not only by written sources but also by the archaeological data.

Key words: eastern sources, historiography, three centers of Rus, Arsa, Arsaniya, Idnakar settlement, Soldyr settlement.

ляет определенную сложность в изучении. Эта сложность объясняется отсутствием современ- 
ных ему источников, созданных на территории Древней Руси. При этом и иностранных источников, позволяющих пролить свет на указанный период нашей истории, крайне мало. Поэтому каждое сообщение, особенно, если автор сообщения - современник описываемых событий, представляет для историков особую ценность. Одним из значимых источников по истории Руси в описываемый период не без оснований считается один из старейших рассказов восточных географов - рассказ о трех центрах русов.

При исследовании вопроса локализации трех центров русов большинство авторов сходилось на соотнесении Славии с Ладогой и позже Новгородом. С Куябой большинство авторов отождествляет Киев. В отличие от первых двух центров третий - Арсания, а в статье [54, с. 418]. А. П. Новосельцев подчеркивает, что правильным произношением является именно «Арсания» и «Арса» а не «Артания» и «Арта», вызывает у ученых разногласия вот уже 200 лет.

В рамках поставленной в настоящей работе задачи произведем сравнительный анализ разных версий локализации трех центров русов которые в значительной степени выливаются в версии локализации Арсании. Представляется рациональным сгруппировать работы историков по географическому принципу.

Сторонниками Азово-Причерноморской (Тмутараканской) версии были Д.И. Иловайский [28] В.А. Пархоменко $[55 ; 56$, с. $72-87 ; 57$, с. 34] С. П. Быковский $[8$, с. 36, 68-70], С. В. Юшков $[81$, с. 37,39$]$, В. В. Мавродин $[46$, с. 205,206$]$ А. М. Карасик, А. Н. Насонов, Г. В. Вернадский. К этой же локализации склонялся и А. И. Соболевский $[70$, с. 55-58] - он предлагал отождествить Арсанию с городом в Крыму (в районе Евпатории). А. М. Карасик [33, с. 304-305] говорит о локализации Арсы на юго-востоке - в Приазовье, Восточном Крыму или на Северном Кавказе. A. Н. Насонов $[53$, с. 80, 81] отождествлял Арсу с Тмутараканью. К этой версии присоединился и Г. В. Вернадский $[88$, с. 198]. В. В. Мавродин [46 c. 205,206$]$ предлагает локализовать Арсанию в Восточном Крыму, так как жители Арсании практикуют ксеноктонию, как и тавры, по свидетельству «Жития Георгия Амастридского» практикующие «древнее таврическое избиение иностранцев». Б. А. Рыбаков в работах 1960-х гг. локализовал Арсанию в Чернигове. Автором «приднепровской» версии был также Б. А. Рыбаков [62, с. 89] - он помещает Арсу и Славию в Поднепровье в один ряд с Куйабой и отождествляет Славу с г. Переяславль, а Арсу - с г. Родень в устье р. Рось. Такая локализация противоречит не только арабским источникам, но и данным археологии, согласно которым в Родне и Переяславле отсутствуют культурные слои IX - первой половины Х в. $[15$, с. 58-59]. А. Н. Карсанов [34, с. 5-13] поместил Арсанию в Галицко-Волынском княжестве. Все представленные теории южной локализации вызывают серьезные сомнения. Главный довод против них приводит А. П. Новосельцев [54, с. 418-419] - ему вполне очевидно северное расположение Арсании - оно следует, например, из предметов экспорта - пушнины и свинца. Собственно, и клинки, вывозимые из Арсании (Худуд ал-Алам), вероятнее всего, северного происхождения.

Сторонниками «прибалтийской» версии выступали Ф. Вестберг, В. Б. Вилинбахов и А. Г. Кузьмин [42, с. 28-55]. Ф. Вестберг [9] искал Артанию в Скандинавии. И. Хрбек [84] пытался доказать, что Арсанийа - западнославянский остров Рюген. Позже с похожими идеями выступили В. Б. Вилинбахов и А. Г. Кузьмин [42, с. 28-55, 43]. В. Б. Вилинбахов $[10$, с. 265-266; 87] помещает Куйабу в польскую Куявию, а Арсанию на основании созвучности названий локализует в Прибалтике, отождествляя ее жителей с прибалтийскими славянами. Гипотеза Вилинбахова хорошо согласуется с сообщениями аль-Хазари, аль-Булгари и гази-Бараджа [6], опубликованными позже появления работы В. Б. Вилинбахова. Согласно источнику, булгары для обозначения Прибалтики использовали слово Артан [6, с. 73]. По-видимому, топоним образован от тюркского названия Балтики - «Артанское море» (Артан дингезе) [6, с. 193] которое, в свою очередь образовано от булгарского названия острова Рюген - также Артан [6, с 25]. По поводу локализации Куябы Вилинбахова у ряда историков (например, А. П. Новосельцева [54, с. 416]) есть следующее возражение: алИдриси сообщает о купцах из Армении, ездящих в Куйабу. Купцы из Закавказья могли по Черному морю или сушей через Северный Кавказ, затем по Дону ездить в Киев, но не в польскую Куявию. Прибалтийская версия значительно убедительнее южной, однако следует вспомнить, что мечи северорусского происхождения двигаются как раз в противоположном направлении - с севера Руси в страны Прибалтики. Кроме того, при такой локализации нарушается требование расположения Арсании между Куябой и Славией (ал-Идриси), хотя его можно и не принимать во внимание полагая вставкой XII в. Собственно, при этой локализации непонятно, почему, например, у алИдриси, инфооматоры которого в Арсании, судя по всему, бывали, в описании не упомянуто море, по которому должны были плыть купцы из Арсании.

«Верхневолжской» версии придерживались В. Ф. Минорский, А. А. Шахматов, Д. Ф. Щеглов, П. П. Смирнов, А. Л. Монгайт, А. П. Новосельцев, Т. М. Калинина, О. В. Фомин, И. В. Дубов, Х. Ловмяньский и др. В. Ф. Минорский $[83$, с. 439] располагал Арсанию в районе р. Оки. А. Л. Монгайт [51, с. 103-112] предлагал вернуться к рязанской теории, принадлежавшей А. А. Шахматову и Д. Щеглову [80, с. 35, примеч.; 81, с. 15], но позднее от нее отказался $[52$, с. 16]. Г. Ф. Корзухина $[40$, c. $34 ; 39$, с.190] предлагает все три центра Руси разместить в Верхнем Поволжье. А. П. Новосельцев [54, с. 418-419] настаивает на северном положении Арсании, на которое указывают вывозимые оттуда продукты - пушнина и свинец или олово. Мех по указанию исследователя вывозился из северных областей, свинец или олово могли приходить с Урала или с Балтики. Также 
А. П. Новосельцев отмечает сообщение о мечах и клинках, вывозимых из Арсании, из которого, основываясь на бытовавшем в то время в исторической науке предположении, что речь идет об импортных мечах, делает вывод, что Арсанию надо искать где-то на торговом пути из Западной Европы. Наконец, на основании данных алИдриси, помещающего Арсанию между Славийей и Куйабой, Новосельцев помещает Арсанию в районе Ростова-Белоозера. Город Арсу он сопоставляет с Сарским городищем недалеко от Ростова. Ко мнению Новосельцева присоединяются Д. А. Мачинский $[49$, с. 3-23] и Т. М. Калинина $[31$, с. 16]. П. П. Смирнов $[67$, с. $168-173$, 203] помещает Куябу в устье Оки, Славию - севернее (Ярославль), а Арсанию - на Оке между ними, возможно, в районе Ардатова. Это предположение не подтверждается археологическими данными. О. В. Фомин (Фомин-Шахов) [77, с. 19 20] локализует Арсанию в междуречье Оки и Волги. Также на этой локализации в разное время настаивали И. В. Дубов $[17$, с. $127 ; 18$, с. 22-29; 19 , с. 104-123] и $X$. Ловмяньский [45, с. 200-201]. При этом, учитывая особенность расположения рек, практически образующих замкнутое кольцо, автор гипотезы говорит об Арсании, как об острове русов восточных географов. Эта группа версий локализации Арсании наиболее отвечает всем предъявляемым к ней требованиям. В качестве возражения этой группе версий (главным образом, А. П. Новосельцеву) К. А. Аверьянов [3, c. 43] приводит цитату из Лаврентьевской летописи [59, стб. 10]: «На Белеозере седять Весь, а на Ростовьском озере Меря». Однако, на основании археологических данных одни ученые $[19$, с. 3345] полагают, что регион волго-клязьменского междуречья был колонизирован новгородцами с начала IX в., другие [66, с. 380] - что приход славян в Волго-Клязьменское междуречье и ассимиляция ими местных финнов относятся примерно к середине первого тысячелетия нашей эры, племя меря же в этот период уже не финское, а славянское: по мнению Седова, славяне переняли этноним ассимилированных финнов. Таким образом, версия локализации Арсании в Волго-Клязьменском междуречье была бы наиболее убедительной, если бы позже не возникла в значительно большей степени соответствующая данным восточных геограсров версия локализации Арсании в Нижнем Прикамье, принадлежащая Д. В. Смокотиной.

Сторонниками «волго-камской версии» были Х. Д. Френ, М. д’Оссон, П. С. Савельев, Р. Хеннинг, Т. Левицкий, А. Л. Монгайт. Х. Д. Френ [82], М. д'Оссон [86] и П. С. Савельев $[64$, с. 91] отождествляли Арсанию с землёй мордовского племени эрзя. Позже к ним присоединился Т. Левицкий $[85$, c. 373]. Версию опровергает отсутствие здесь археологических памятников соответствующего времени. Ж. Т. Рено [87] и Д. А. Хвольсон [23, c. 174] искали Арсанию в Перми. Эту версию опровергают современные данные об этническом составе населения верхнего Прикамья в IX-XII вB. Р. Хенниг помещает Арсанию в районе Чердыни в
Предуралье [78, с. 269]. А. Л. Монгайт [61, с. 102103] сопоставлял Арсанию восточных источников и Ару, описанную Абу-Хамидом ал-Гарнати, которую отождествлял с Арской землей русских летописей, расположенной на Нижней Каме. Эта версия позже будет развита Д. В. Смокотиной, чья локализация Арсании представляется наиболее убедительной из существующих сегодня

Апологетами «аланской» версии являются А. Г. Кузьмин и Е. С. Галкина. А.Г Кузьмин [43, c. 256], предполагает, что речь у восточных авторов ведется о трех разных народах, а «третья Русь», по его мнению, Русь аланская, и помещает ее в областях Подонья (салтово-маяцкая культура). Е. С. Галкина в работе «Тайны русского каганата» $[11$, с. 139-143, 187-235] отождествляет русский каганат с салтово-маяцкой культурой, похожая позиция озвучена в ряде совместных с А. Г. Кузьминым работ, то есть, не касаясь локализации Арсании, Е. С. Галкина также, как А. Г Кузьмин, признает «русов» IX в. аланами. Версия эта, как минимум, не соответствует требованию северного расположения Арсании. Кроме того, скажем, для XII В., в котором творил ал-Идриси, для географра путать русов и алан весьма странно.

В связи с Нижней Волгой имеет смысл упомянуть две версии. Д. В. Смокотина $[68$, с. 8-10] приводит версию, основанную на ряде работ В. Н. Топорова $[75 ; 73 ; 74 ; 76]$, в которой связывает Арсанию с хазарской гвардией «ал-арсия», которая по сообщениям ряда восточных источников (напр. ал-Масуди [1, с. 10-11]) имела славянское происхождение. Следует заметить, что большинство исследователей ал-арсию относит к хорезмийцам. Утверждение же о ее мусульманском вероисповедании, по-видимому, ошибочно. Это мнение основано на старом и неточном переводе «Золотых копей ...»: «Ларсия же и другие мусульмане из страны Хазар» тогда как, в более позднем переводе Т. М. Калининой [16] ал-арсия четко противопоставлена мусульманам: «ал-арсийа и те, кто в их [хазар] царстве из мусульман». В. Н. Топоров подчеркивает, что ал-арсия, будучи язычниками, бежали из Хорезма именно от исламизации. Относительно этнической принадлежности ал-арсии в науке существует мнение, что ал-арсия - это жившие в древности на востоке от Каспия предки современных осетин - иранские аланы или асы [22, с. 128, 156]. При этом также, возможно, что слово «арсийя» образовано от этнонима «аорсы», известной в древности разновидности массагетов (иранских племен), как раз обитавшей в описываемой области - хоть, как принято считать, аорсы к описываемому времени не существовали, сами массагеты или аланы могли сохранить свое старое название. На существование русского или славянского войска у хазар указывает Артамонов в “Истории хазар» [4, c. 383]. Версия В. Н. Топорова, безусловно, оригинальна и, в общем, важна, как затрагивающая важный вопрос - этнического состава населения Хазарского каганата, однако, помимо традиционных для южной локализации возражений, встречает еще одно. Дело в том, что Арсания у вос- 
точных авторов описана, как свободный народ, а хазарская гвардия - люди, обремененные должностными обязанностями внутри другой страны. В работе «Арса: место на карте (К вопросу о локализации третьего центра Руси)" [68 с. 12-13] Д. В. Смокотина предлагает еще одну концепцию: отождествление Арсы с землей или городом Буртас в Среднем и Нижнем Поволжье (примерно от современного Саратова до современного Волгограда). А буртасы по одной из этнологических теорий имеют славянское происхождение (Н. Ф. Калинин [32, с. 61-63], В. Ф. Генинг [12], Е. П. Казаков [29; 30] и другие считали буртасов потомками племен именьковской археологической культуры.). Кроме того в книге «История Хазарии» Абдаллаха ал-Хазари [6, с. 25] указывается, что имя буртасов получили колонисты из Северной (ладожской) Руси, переселившиеся на Нижний Дон в 745 г., а затем распространившиеся на территорию хазар. Д. В. Смокотина предлагает цепочку: Буртас - Уртас - Урта - Арта - Артания. В поддержку названной концепции Смокотина указывает, что буртасы известны, в частности, как торговцы, а в их торговле одним из главных товаров были меха. При этом черно-бурые лисьи меха, пользующиеся особой популярностью, даже назывались буртасскими. При этом пушнина - один из товаров, привозимых из Арсании. Версия эта, однако, может быть отвергнута с рядом оснований. Первое основание, конечно, В том, что Буртас находится на юге, а Арсания, как было показано выше, на Севере. Второе - Буртас находится слишком близко от арабских земель и слишком хорошо описан в восточных источниках для того, чтобы восточные авторы не смогли его отождествить с малоизвестной им Арсанией и вряд ли булгары смогли бы утверждать, что Куяба самый близкий к Болгару вид русов, если бы Арсания располагалась непосредственно на границе Булгарии, причем на юге под самым носом арабов.

Безрезультатность поисков Арсании привела к появлению в историографии направления, сторонники которого полагали Арсанию не географическим понятием, а просто нарицательным выражением. Например, А. М. Карасик [33, с. 304-305] предлагал переводить имя «Артания» с угрского наречия как «страна на запоре». По мнению В. Я. Петрухина [58, с. 143-158], Арсания есть не реальный центр, а контаминация сведений славянского информатора восточных авторов о первых двух центрах или о Древней Руси вообще, вызванная востребованностью тернарной структуры, свойственной славянской традиции А. Ф. Студенцов $[72$, с. 49$]$ пытался отождествить Арсу с ветхозаветной страной Арсарет.

В последнее время ряд историков вернулся к старой точке зрения, представлявшей три центра русов реальными географическими объектами. В 1990-е гг. глубокий анализ проблемы, в частности включающий обширную историографическую справку, был произведен И. Г. Коноваловой [37, с. 139-148]. По заключению автора [37, с. 144-145] восточные географы XII-XIV вв. уже не имели све- дений о первых двух центрах русов, как о реалиях их времени. Поэтому они либо просто переписывали сообщения X в., либо пытались их как-то адаптировать к своей системе знаний. Относительно же Арсы-Арсании аль-Идриси существенно дополняет предшественников. То есть Арса существовала в его время и вполне вписывалась в современные ему географические представления. При этом характер его сведений о городе Арса свидетельствует, что его информаторы булгары - в Арсе бывали и город хорошо знают.

Из публикаций по данному вопросу, появившихся за последнее время, полагаем заслуживающими внимания как наиболее взвешенные и научные две относительно новые точки зрения.

Д. В. Смокотина в статье «Арса: место на карте» [68, с. 14-16], предложила новый подход к решению проблемы третьего центра русов. В своих работах Смокотина, опираясь на изучение источников и археологические данные, локализует Арсанию в Прикамье (подобная локализация предлагалась А. Л. Монгайтом [61]). Позже в кандидатской диссертации [69, с. 16] Д. В. Смокотина обобщила свой подход и добавила ряд географических подробностей. В частности, она уже уверенно отождествляет город Арсу с городищем Иднакар.

К. А. Аверьянов [2; 3, с. 46-47], используя сообщение арабских авторов о расположении трех центров русов на одной реке, причем Арсы между Куябой и Славией (по ал-Идриси), а также позднее (XII в.) сообщение ал-Идриси о расстояниях между центрами русов по четыре дня пути, локализует Арсанию в районе Гнездовского городища на Днепре, а отголосок её названия видит в соседнем городе Орша, правда, появившемся, по меньшей мере, на сто лет позже.

Сравним представленные версии

Прикамская Арсания находится на одном водном пути с Куябой и Славией. А именно, водный путь из смокотинской Арсании действительно ведет и в Киев (Волга-Ока-Днепр) и Новгород (Великий волжский путь), и при этом восточные географы все реки Древней Руси объединяли в одну реку Рус [38] - ее, возможно, и полагали водным путем Славия-Арса-Куяба. Сообщение ал-Идриси о расположении Арсании между Куябой и Славией можно объяснить при такой локализации очень просто: для того, чтобы добраться до Арсании из Славии надо спуститься по воде, не проходя через Куябу, а в Куябу купцы из Арсании приходят сверху, также минуя Славию. По поводу локализации Аверьянова: на середине пути по Днепру между Новгородом и Киевом действительно находится Гнездовское городище, соответствующее периоду со второй половины IX до начала XI в. [13, с. 4-6]. Выкладки Аверьянова относительно скорости в 150 км в день, с которой передвигались по воде древние русы, выглядят убедительно. Здесь, правда, следует сделать одно замечание. Аверьянов апеллирует к сведениям ал-Идриси о расстоянии в четыре дня пути от Славии до Арсании и от Арсании до Куябы, но ал-Идриси писал уже в XII в., когда, как отмечает 
И. Г. Коновалова [37, с. 144-145], уже не было ни Куябы, ни Славии. Таким образом, даже при том, что, как отмечает И. Г. Коновалова, Арсания при Идриси еще существовала в том или ином виде, получить от своих информаторов информацию о расстоянии между центрами русов ал-Идриси не мог. Вообще в историографии принято считать, что большая часть информации Идриси восходит к произведениям авторов IX-X В. [71, с. 125], однако, информации о расстоянии между центрами русов нет ни у одного автора, кроме Идриси. Видимо, следует полагать, что расстояние - изобретение самого Идриси. К такому выводу пришел А. Л. Монгайт [51, с. 104], считая сообщение вставкой XII в. И. В. Дубов же отмечает несоответствие данных текста ал-Идриси и его карты, где расстояния между центрами русов не равные $[19$, с. 104-123]. Соответственно, К. А. Аверьянов, доказывая, что такое расстояние возможно в том или ином варианте локализации, напрасно тратил время. Далее, К. А. Аверьянов в обеих указанных работах не касается остальной информации восточных географов, а именно, пушнины, свинца и особо ценных клинков (Худуд ал-алам), экспортируемых Арсанией. Эта информация в корне меняет дело: пушнина по всей вероятности экспортировалась из северных регионов, кроме того, ал-Истахри прямо сообщает о северном расположении Арсании (по указанию В. Ф. Минорского [50, с. 197] в одной из рукописей ал-Истахри говорится: «земля Арта прилегала к северной необитаемой пустыне»). Свинец или олово происходили с Урала или с Балтики [54, с. 419]в случае правильности аверьяновской локализации Арсании при обоих вариантах его происхождения их источником оказался бы другой центр русов - вероятнее всего, Славия. Наконец, подчеркнутые персидским анонимом особо ценные клинки, по-видимому, отличаются от тех, которые производятся в Новгороде и Киеве, а Смоленск относится фрактически к тому же региону Руси, что и Новгород с Киевом, следовательно, и традиции производства мечей были теми же.

У гипотезы Д. В. Смокотиной значительно больше оснований. Во-первых, как уже выше указывалось, Арсания находится на севере Древней Руси, во-вторых, связана с Киевом и Новгородом водным путем. Здесь Прикамье удовлетворяет. Следующим доводом в пользу правильности гипотезы, могут послужить сообщения восточных авторов о товарах, привозимых из Арсании. Пушнина может быть как местного происхождения, так и привозной - происходить из земель народов Вису и Йура, из земель которых по данным тех же восточных источников (например, по сведениям ал-Гарнати [61], восходящим к источникам $X$ в. $[6$, с. $18-19,76-77])$ привозится мех и «рыбьи зубы», а дорога по сообщениям восточных географров проходит как раз через нижнее Прикамье. Следует заметить, что земли Вису и Иура, как правило, отождествляют с Весью и Югрой (см., например, Б.Н. Заходер [22, с. 59-67], О. Г. Большаков [61, с. 101-105]), хотя если подробно следовать описаниям, данным Абдаллахом ал-Хаза- ри, то Вису следует отождествлять с бассейном Печоры, что делает, например, Р. Хенниг в [78]. Свинец или олово могли привозиться с Урала [54, с. 419], соседствующего с Прикамьем. Следующий довод в пользу исследуемой гипотезы - сообщение ибн-Хаукаля [54, с. 412], согласно которому, Булгар Великий граничит с Арсанией на севере: на севере от Булгарии только Прикамье. В процессе анализа гипотезы необходимо ответить на вопрос, почему Арсания с указанной локализацией считается не самым близким к Болгару видом русов. Это можно объяснить существованием сухопутного пути между Киевом и Болгаром $[63$, с. $86-196 ; 60$, с. $316-326]$, но отсутствием такового между Болгаром и Арсой. Таким образом, о пути (водном) Болгар-Арса - о маршруте, длине и других подробностях - булгары могли только догадываться. Возможно и другое объяснение. Как отмечает И. Г. Коновалова [37, с. 143], фразу о том, что Куяба - ближайший к Болгару пункт, можно воспринимать, например, как сообщение о наиболее тесных торговых отношениях. В этом случае противоречие снимется само собой. К приведенным доводам следует добавить, что река Итиль по сообщениям ряда восточных авторов (ал-Истахри, ибн-Хаукаль) выше Булгара проходит через земли русов $[16$, с. 85,93$]$. Учитывая то, что в восточной географии Итиль проходил по Каме, а не по Верхней Волге, никакой другой «Руси», кроме как прикамской, на Итиле выше Булгара быть не могло. Дополнительным аргументом в пользу смокотинской локализации является расположение Иднакара на горе (г. Солдырь) и довольно высокие фортификационные качества крепости $[41$, с. 38-63] - ведь именно это об Арсе сообщает ал-Идриси.

Итак, из двух последних локализаций Арсании значительно более обоснована локализация в Прикамье, принадлежащая Д. В. Смокотиной.

К сожалению, до определенного времени подобные гипотезы не могли быть предложены. Невозможность подобного решения была обусловлена традиционными представлениями о населении описываемых областей. Как было принято считать до недавнего времени, эти территории были заселены так называемыми «серебряными» булгарами или булгарами камскими, удмуртами, коми и т.п. Пожалуй, переломным моментом в развитии исторического знания явилась докторская диссертация Л. Д. Макарова [47] и ряд предшествовавших ей работ этого же автора. В указанной работе автор на основании лингвистических, источниковедческих и археологических данных делает вывод о древнерусской колонизации территории, описанной нами, как Арсания, по меньшей мере, с начала Х в. Исследователь приводит генезис понятия «Серебряные булгары» от названия реки Вятки «Нукрат», которое представляет собой искажение от слова «Новгород" (здесь Л. Д. Макаров ссылается на мнение лингвистов $[5$, с. 44-45; 14, с. 149-154]), а «Нукрат-су» - соответственно, Новгородская река. Так что «нукратские булгары» не «серебряные» (от арабского слова «нократ» - «серебро»), 
а «болгары, проживавшие около новгородской реки». В дополнение к работам Л. Д. Макарова можно привести позицию В. В. Седова [65, с. 60, 61], позже распространенную в работе М.И. Жиха [20]. Согласно исследователям, часть представителей именьковской культуры, традиционно считающейся славянской, существовавшей на Средней Волге c IV по VII в., после миграции основной массы «славян-именьковцев» на Средний Дон (волынцевская культура) осталась на старых местах, и очаги славянской культуры зафиксированы по всему ареалу распространения булгар Свои заключения автор подкрепляет ссылкой на археологические данные и анализ восточных источников, таких, как «Письмо Иосифа» [36], ал-Истахри $[48$, с. 227; 7]. Таким образом, русь Л. Д. Макарова, начавшие колонизацию Прикамья в X в., приезжали к своим соотечественникам. Обобщением всех вышеуказанных взглядов вполне может явиться идея А. Н. Кирпичникова [35]. Согласно исследователю, в торговых целях славяне, а позже северные русы создают города-фактории вниз по Волжскому пути - городища Тимерево, Петровское и Михайловское на месте Ярославля, Сарское - предшественник Ростова, Суздаль, Клещин - предшественник Переяславля-Залесского, Муром на Оке, поселение на средней Волге, предшествующее Казани. Таким образом, “северные русы» «подхватывали» обнаруживаемые ими на ВВП славянские центры и превращали их в города-фрактории. Так происходило заселение волго-клязьменского междуречья, рядом исследователей отождествляемого с «островом русов» восточных источников. Так колонизировалась, по мнению М. И. Жиха [20], Средняя Волга и так колонизировалось Нижнее Прикамье. Археологические изыскания также подтверждают проживание русов в «городе». М. Г. Иванова $[24$, с. $48-61 ; 25 ; 26$, с. $119-125]$ указывает, что на городище Иднакар уже в слояX X-XI вв. обнаружены славянские вещи (шиферные пряслица, футляры складных расчесок, двусторонние роговые гребни, украшения, орудия труда, оружие). Исследователь также отмечает, что ассортимент, фоомы и технологии металлоизделий местного производства полностью со- ответствуют традициям мастеров Древней Руси $[24$, с. $48-61 ; 25 ; 26$, с. $119-125 ; 21$, с. 119-142], что, по мнению исследователя, означает именно постоянное проживание древнерусских мастеров в «городе». В частности, в регионе было распространено производство мечей так называемого франкского типа, являвшееся, по указанию В. И. Завьялова $[21$, с. $119-142 ; 27$, с. 7-14], составной частью северорусского металлообрабатывающего производства, для которого было характерно сочетание в орудии при помощи кузнечной сварки твердого стального лезвия и более мягкой основы. Вероятно, именно об этих мечах и сообщает автор Худуд ал-алам в рассказе об Арсании. Также непосредственно о проживании в регионе и «городе» русов говорят костяные предметы X-XI вв. с признаками властной принадлежности: гребень с княжеским знаком Рюриковичей, древнерусская печать в форме шахматной фигурки с монограммой «м». Все вышеуказанные находки сочетаются с распространенной в регионе так называемой славяноидной керамикой, характерной для частично ассимилированного аборигенного населения. Таким образом, мы можем говорить не просто о широком присутствии славянского компонента в этническом составе населения, но - плотном симбиозе славянского и аборигенного финского населений, впоследствии приведшего к частичной ассимиляции последнего.

И последнее. Так как большая часть сведений арабов получена ими от булгар или через посредство булгар, а, например, ал-Гарнати ссылается непосредственно на булгарского автора Йакуба ибн Нугмана аль-Булгари [6], то и название земли, вероятно, получено от них же. То есть оно должно фригурировать и в булгарских источниках. В Хазар-тарихы и Кади-китабы [6, с. 38-39, 187] область Нижнего Прикамья названа именем Арча также, как и ее центр - город Арча. Но город Арча в более поздних тюркских источниках $[6$, с. 236] отождествляется с Арском. При этом археология пока не дает подтверждения существования Арска в исследуемый период. Так что, вероятно Арса-Арча - ойконим, соответствующий двум разным городам - сначала предлагаемому Смокотиной Иднакару, а с XIII в. - Арску.

\section{Источники и литература}

1. Абу-л-Хасан 'Али ибн ал-Хусайн ибн 'Али ал-Масуди. Золотые копи и россыпи самоцветов. М.: Наталис, 2002 $803 \mathrm{c}$.

2. Аверьянов К. А. К вопросу о трех центрах Руси // Источниковедческая компаративистика и историческое построение. Тез. докл. и сообщ. науч. конф. М.: РГГУ, 2003, №1 (67).

3. Аверьянов К. А. С какой скоростью передвигались в Древней Руси во времена князя Владимира? // Вестник славянских культур. 2016. №1. С. 41-52.

4. Артамонов М.И. История хазар. Л.: Издательство государственного Эрмитажа, 1962. 521 с

5. Ахметзянов М.И. Нократ иделе // Офык. 1991. №4. С. 44-45.

6. Бахши Иман. Джагфар Тарихы. Т. 1. Оренбург: Болгария, 1993. 400 c.

7. Большаков О.Г. Ал-Истахри - Ибн Хаукаль // История татар с древнейших времен. Т.ІІ. Казань: РукИЛ, 2006 C. $745-752$.

8. Быковский С. П. К вопросу о трех древнейших центрах Руси // Труды Вятского педагогического института. Т.3 Вып. 6. Вятка: Вятск. пединст-т им. В.И. Ленина, 1928. С. 36, 68-70.

9. Вестберг Ф. К анализу восточных источников о Восточной Европе // Журнал Министерства народного просвещения. 1908. №2-3. С. 1-52.

10. Вилинбахов В.Б. Балтийские славяне и Русь // Slavia Occidentalis. Poznań, 1962. T.22. С. 254-277. 
11. Галкина Е. С. Тайны Русского каганата. М.: Вече, 2002. 432 с.

12. Генинг В. Ф., Халиков А. Х. Ранние болгары на Волге. М.: Наука, 1964. 201 с.

13. Гнездово. Результаты комплексных исследований памятника. СПб.: Альфарет, 2007. 330 с

14. Добродомов И. Г. Нукрат (татарское название Вятки) // История и культура Волго-Вятского края (к 90-летию Вятской ученой архивной комиссии). Тезисы докладов и сообщений к межрегиональной научной конференции. Киров: Волго-Вятское кн. изд-во, 1994. С. 279-281

15. Древняя Русь. Город, замок, село. Серия. Археология СССР. М.: Наука, 1985. 425 с.

16. Древняя Русь в свете зарубежных источников: Хрестоматия. М.: Русский Фонд Содействия Образованию и Науке, 2009. $264 \mathrm{c}$.

17. Дубов И. В. Великий Волжский путь. Л.: Изд-во Ленингр. ун-та, 1989. 256 с.

18. Дубов И. В. Северо-Восточная Русь и «Арса» арабских источников // Вестник Ленинградского университета. 1981. №8. История, язык, литература. Вып. 2. С. 22-29.

19. Дубов И. В. Северо-восточная Русь в эпоху раннего средневековья. Ленинград: Издательство Ленинградского университета, 1982. $255 \mathrm{c}$.

20. Жих М. И. Ранние славяне в Среднем Поволжье. СПб.; Казань: Вестфалика, 2011. 90 с.

21. Завьялов В. И. Кузнечное ремесло северных удмуртов в конце I - начале II тысячелетия н. э. // Новые исследования по древней истории Удмуртии. Ижевск: Удмуртский ин-т истории, языка и литературы Уральского отделения $\mathrm{PAH}, 1988$. С. 119-142.

22. Заходер Б. Н. Каспийский свод сведений о Восточной Европе. М.: Наука, 1967. 213 с.

23. Ибн-Даста Известия о хозарах, буртасах, болгарах, мадьярах, славянах и руссах. Спб.: Тип. Императорской академии наук, 1869. $199 \mathrm{c}$.

24. Иванова М. Г. Древнеудмуртское городище Иднакар IX-XIII вв.: новые результаты и перспективы исследований // Ежегодник финно-угорских исследований. 2009. №1. С. 48-61.

25. Иванова М. Г. Иднакар: Древнеудмуртское городище IX-XIII вв. Ижевск: Удмуртский ин-т истории, языка и литературы Уральского отделения РАН, 1998.

26. Иванова М. Г. Средневековые городища Прикамья в контексте процессов градообразования // Материалы и исследования по средневековой археологии Восточной Европы. Казань: Школа, 2009. С. 119-125.

27. Иванова М. Г., Завьялов В. И. Древнеудмуртские кузнецы // Вестник РГНФ. 2001. №1. С. 7-14

28. Иловайский Д. И. Разыскания о начале Руси. М.: Тип. Грачева и К, 1876.466 с.

29. Казаков Е. П. Культура ранней Волжской Болгарии. М.: Наука, 1992. 335 с

30. Казаков Е. П. Хронологические этапы взаимодействия сармат с поволжскими финнами в средние века. // Вестник Казанского государственного университета культуры и искусств. 2015. № 2-4.

31. Калинина Т. М. Древняя Русь и страны Востока в Х в. (Средневековые арабо-персидские источники о Руси): автореф. ... дисс. канд. ист. наук. М., 1976. 31 с.

32. Калинин Н. Ф., Халиков А. Х. Итоги археологических работ за 1945-1952 гг. // Труды Казанского филиала Академии наук СССР. Казань, 1954. С. 61-63.

33. Карасик А. М. К вопросу о третьем центре Руси // Исторические записки 1950. Т.35. С. 304-305

34. Карсанов А. Н. К вопросу о трех группах русов // Герменевтика древнерусской литературы X-XVI вB. Сб. 3. М.: Институт мировой литературы РАН, 1992. С. 5-13.

35. Кирпичников А. Н. Великий волжский путь и ладожско-волховский север Руси в эпоху раннего средневековья. // Ладога и Ладожская земля в эпоху средневековья. Вып. 1. С.-Пб.: Нестор-История, 2006. С. 5-12

36. Коковцов П. К. Еврейско-хазарская переписка в Х в. Л.: АН СССР, 1932. XXXVIII+134+4 табл.

37. Коновалова И. Г. Рассказ о трех группах русов в сочинениях арабских авторов XII-XIV вв. // Древнейшие государства Восточной Европы. 1992-1993. М.: Наука, 1995. С. 139-148.

38. Коновалова И. Г. Топоним как способ освоения пространства («Русская река» ал-Идриси) // Диалог со временем: Альманах интеллектуальной истории. 2001. Вып. 6. С. 192-219.

39. Корзухина Г. Ф. Путь Абу-Хамида ал-Гарнати из Болгара в Венгрию // Проблемы археологии. Сб. ст. Вып. ІІ. Л.:

лГУ, 1978. С. 189-195.

40. Корзухина Г. Ф. Русские клады. М.: АН СССР, 1954. 226 с.

41. Коробейников А.В. Иднакар и анализ городищு с позиций их уровня защиты // Иднакар, 2008. № 4. С. 38-63.

42. Кузьмин А. Г. «Варягии» и «Русь» на Балтийском море // Вопросы истории. 1970. №10. С. 28-55.

43. Кузьмин А. Г. Крещение Киевской Руси. М.: Алгоритм, 2012. 272 с.

44. Кузьмин А. Г. Начало Руси. М.: Вече, 2003. 630 с.

45. Ловмяньский Х. Русь и норманны. М.: Прогресс, 1985. 304 с.

46. Мавродин В. В. Образование Древнерусского государства. Л.: Изд-во Ленингр. ун-та, 1945.432 с.

47. Макаров Л. Д. Древнерусское население Прикамья в X-XV веках. Ижевск: Удмуртский государственный университет, 2006. $143 \mathrm{c}$.

48. Материалы по истории туркмен и Туркмении, Том I. VII-XV вв. Арабские и персидские источники. М.-Л.: АН CCCP, 1939. $612 \mathrm{c}$.

49. Мачинский Д. А. Ростово-Суздальская Русь в Х в. и «три группы Руси» восточных авторов // Материалы к этнической истории Европейского Северо-Востока. Сыктывкар: Пермский ун-т, 1985. С. 3-23. $270 \mathrm{c}$

50. Минорский В. Ф. История Ширвана и Дербенда в X-XI веках. М.: Издательство восточной литературы, 1963.

51. Монгайт А. Л. К вопросу о трех центрах древней Руси // Краткие сообщения Института истории материальной культуры. 1947. Вып. XVI. С. 103-112.

52. Монгайт А. Л. Рязанская земля. М.: АН СССР, 1961. 400 с. 
53. Насонов А. Н. Тмутаракань в истории Восточной Европы // Исторические записки. 1940. Т.6. С.79-99.

54. Новосельцев А. П. Восточные источники о восточных славянах и Руси VI-IX вв. // Древнерусское государство и его международное значение. М.: Наука, 1965. С. 355-419.

55. Пархоменко В. А. Начало христианства Руси. Полтава: Тип-я Г. И. Маркевича, 1913. 191+IV c

56. Пархоменко В. А. Три центра древнейшей Руси // Известия Отделения русского языка и словесности. Т. ХVIII, Кн. 2. СПб, 1913. С. $79-87$.

57. Пархоменко В. А. У истоков русской государственности. Л.: Госиздат, 1924. 116 с

58. Петрухин В. Я. Три «центра» Руси. Фольклорные истоки и историческая традиция.//Художественный язык средневековья. М.: Наука, 1982. С. 143-158.

59. Полное собрание русских летописей. М.: Языки русской культуры, 1997. Т. І. 496 с.

60. Полубояринова М. Д. Путь из Булгара в Киев. Торговые связи с Киевской Русью и древнерусскими княжествами // История татар. Т.ІІ. Волжская Булгария и Великая степь. Казань: РухИЛ, 2006. С. 316-326.

61. Путешествие Абу Хамида ал-Гарнати в Восточную и Центральную Европу. М.: Главная редакция восточной литературы, 1971. 137 с.

62. Рыбаков Б. А. Киевская Русь и русские княжества XII-XIII вв. М.: Наука, 1982. 592 с.

63. Рыбаков Б. А. Путь из Булгара в Киев // Древности Восточной Европы. Материалы и исследования по археологии СССР. 1969. №169. С. 186-196.

64. Савельев П. С. Мухаммеданская нумизматика в отношении к русской истории. СПб.: [6.и.], 1846.180 с.

65. Седов В. В. Древнерусская народность. М.: Языки русской культуры. 1999. 317 с.

66. Седов В. В. Славяне. Историко-археологическое исследование. М.: Языки славянской культуры, 2002.624 с

67. Смірнов П. П. Волзький шлях і стародавні Руси. Киів: [б.и.], 1928. 228 с.

68. Смокотина Д. В. Арса: место на карте // Вестник Томского государственного университета. История. 2008. №2

C. $5-17$.

69. Смокотина Д. В. Балтийско-Каспийский торговый путь в эпоху раннего средневековья (VII-IX вв.): автореф.

дисс. ... канд. ист. наук. Томск, 2012. 24 с.

70. Соболевский А. И. “Третье» русское племя // Доклады АН СССР. 1920. №4. С. 55-58.

71. Степаненко В. П. К истории средневековой Таврики // Византия и средневековый Крым. Античная древность и средние века. Вып. 26. Барнаул: День, 1992. С. 125-133.

72. Студенцов А. Ф. Тайна происхождения Древней Руси. Ростов н/Д.; СПб.: Феникс, 2006. 285 с

73. Топоров В. Н. Еврейский элемент в Киевской Руси // Славяне и их соседи. Еврейское население Центральной, Восточной и Юго-Восточной Европы: Средние века - начало Нового времени. М.: Ин-т славяноведения и балканистики РАН, 1993. С. 28-42.

74. Топоров В. Н. Об иранском элементе в русской духовной культуре // Славяне и их соседи. М.: Ин-т славяноведения и балканистики РАН, 1993.

75. Топоров В. Н. Работники одиннадцатого часа. “Слово о законе и благодати» и древнерусская реальность // Russian Literature. 1988. Vol. XXIV. C. 25-26.

76. Топоров В. Н. Святость и святые в русской духовной культуре. Т. І. М.: Языки русской культуры, 1995.875 с.

77. Фомин О. Священная Артания, М.: Вече, 2005. $432 \mathrm{c.}$

78. Хенниг Р. Неведомые земли. Т. ІІ. М.: Изд-во иностранной литературы, $1961.520 \mathrm{c.}$

79. Шахматов А. А. Древнейшие судьбы русского племени. Петроград: издание Русского исторического журнала. 1919. $64 \mathrm{c}$.

80. Щеглов Д. Ф. Первые страницы русской истории. Журнал Министерства народного просвещения. 1876. Ч. CLXXXV. C. $45-112$.

81. Юшков С. В. К вопросу о происхождении Русского государства // Учёные записки МЮИ. Вып. IV. М.: Юрид. издво НKЮ CCCP, 1940. С. 37-59.

82. Fränn C. M. Ibn Foszlan's und anderer Araber Berichte uber die Russen alterer Zeit. SPb., 1828

83. Hudud al-'Alam: «The Regions of the World». London, 1937.

84. Hrbek J. Der dritte Stamm der Rus nach arabischen Quellen//Archiv Orientalni Praha, 1957. T. 25.

85. Lewicki T. Swiat slowianski w oczach pisarzy arabskich // Slavia Antiqua. Poznań, 1949/1950. T. II. s. 373.

86. Mouradja d'Ohsson A.C. Des peuples du Caucase et du Nord de la Mer Noire dans le 10 siecle. Paris, 1828.

87. Reinaud M. Geographie d'Aboulteda. I. Introduction generale a la geographie des Orientaux. Paris, 1848.

88. Vernadsky G. The Origins of Russia. Oxford. At the Clarendon Press. 1959. 354 p.

89. Wilinbachow W.B. Przyczynek do zagadnienia trzech osrodkow dawnej Rusi // Materyaly Zachodnio-Pomorskie Szczecin, 1961. T. VII. S. 517-530.

\section{References}

1. Abu-I-Hasan 'Ali ibn al-Husajn ibn 'Ali al-Masudi. Zolotye kopi i rossypi samocvetov (Gold mines and placers of gems). Moscow: Natalis, 2002. 803 p. (In Russian).

2. Aver'yanov K. A. K voprosu o trekh centrah Rusi (On the three centers of Rus) // Istochnikovedcheskaya komparativistika $\mathrm{i}$ istoricheskoe postroenie. Moscow: Russian state humanitarian university, 2003. (In Russian).

3. Aver'yanov K. A. S kakoj skorost'yu peredvigalis' v Drevnej Rusi vo vremena knyazya Vladimira? (What Speed Did They Move in Ancient Rus During the Reign of Prince Vladimir?) // Vestnik slavyanskih kul'tur. 2016. No.1. P. 41-52. (In Russian).

4. Artamonov M. I. Istoriya hazar (The History of Khazars). Leningrad: State Ehrmitazh, 1962. 521 p. (In Russian).

5. Ahmetzyanov M. I. Nokrat idele // Ofyk. 1991. No.4. (In Russian).

6. Bahshi Iman. Dzhagfar Tarihy. Vol. 1. Orenburg: Bolgariya, 1993. 400 p. (In Russian).

7. Bol'shakov O.G. Al-Istahri - Ibn Haukal'. Istoriya tatar. Vol.II. Volzhskaya Bulgariya i Velikaya step', Kazan', 2006.

P. 745-752. (In Russian). 
8. Bykovskij S. P. K voprosu o trekh drevnejshih centrah Rusi (On the Three Ancient Centers of Rus) // Proceedings of Vyatka pedagogical institute. Vol.3. Issue.6. Vyatka, 1928. (In Russian).

9. Vestberg F. Kanalizu vostochnyh istochnikov o Vostochnoj Evrope (Analysis of Oriental Sources about Eastern Europe) II Zhurnal Ministerstva narodnogo prosveshcheniya. 1908. No.2-3. P. 1-52. (In Russian).

10. Vilinbahov V. B. Baltijskie slavyane i Rus' (The Baltic Slavs and the Rus). Slavia Occidentalis. Poznan', 1962, Vol. 22. P. 254-277. (In Russian)

11. Galkina E. S. Tajny russkogo kaganata (The Secrets of Russian Kaganate). Moscow: Veche, 2002. 432 p. (In Russian).

12. Gening V. F., Halikov A. H. Rannie bolgary na Volge (Early Bulgarians on the Volga). Moscow: Nauka, 1964. 201 p. (In Russian).

13. Gnezdovo. Rezul'taty kompleksnyh issledovanij pamyatnika (Gnezdovo. The Results of Complex Studies of the Monument). St. Petersburg: Al'faret, 2007. 330 p. (In Russian).

14. Dobrodomov I. G. Nukrat (tatarskoe nazvanie Vyatki) (Nukrat (Tatarname of Viatka) // Istoriya i kul'tura Volgo-Vyatskogo kraya. Kirov, 1994. P. 279-281. (In Russian).

15. Drevnyaya Rus'. Gorod, zamok, selo. (Ancient Rus. Town, Castle, Village) // Archeology of USSR. Moscow: Nauka, 1985. 425 p. (In Russian).

16. Drevnyaya Rus' v svete zarubezhnyh istochnikov (Ancient Rus in the Light of Foreign Sources). Moscow: Russian Fund of assistance to education and science, 2009. 264 p. (In Russian).

17. Dubov I. V. Velikij volzhskij put' (The Great Volga route). Leningrad: Leningrad university, 1989. 256 p. (In Russian).

18. Dubov I. V. Severo-Vostochnaya Rus' i «Arsa» arabskih istochnikov (North-Eastern Rus and "Arsa" in Arabian Sources) // Vestnik of Leningrad university. 1981. No. 8. Istoriya, yazyk, literature. Issue. 2. P. 22-29. (In Russian).

19. Dubov I. V. Severo-vostochnaya Rus' v ehpohu rannego srednevekov'ya (North-Eastern Rus in the Early Middle Ages). Leningrad: Leningrad university, 1982. (In Russian).

20. Zhih M. I. Rannie slavyane v Srednem Povolzh'e (Early Slavs in the Middle Volga Region). St. Petersburg; Kazan': Vestfalika, 2011. 90 p. (In Russian).

21. Zav'yalov V. I. Kuznechnoe remeslo severnyh udmurtov $v$ konce I - nachale II tysyacheletiya $n$. eh. (Smithing of Northern Udmurts at the End of I - Beginning of // Millennium BC) // Novye issledovaniya po drevnej istorii Udmurtii. Izhevsk: Udmurt Institute of history, language and literature, 1988. P. 119-142. (In Russian)

22. Zahoder B. N. Kaspijskij svod svedenij o Vostochnoj Evrope (The Caspian Collection of Information about Eastern Europe). Moscow: Nauka, 1967. 213 p. (In Russian).

23. Ibn-Dasta Izvestiya o hozarah, burtasah, bolgarah, mad'yarah, slavyanah i russah (Information about Khazars Burtases, Bulgarians, Magyars, Slavs and Ruses). St. Petersburg: Printing house of the Imperial Academy of Sciences, 1869. 199 p. (In Russian).

24. Ivanova M.G. Drevneudmurtskoe gorodishche Idnakar IX-XIII vv.: novye rezul'taty i perspektivy issledovanij (Ancient Udmurtian Settlement Idnakar IX-XIII Centuries: New Results and Prospects of Research) // Ezhegodnik finno-ugorskih issledovanij. 2009. P. 48-61. (In Russian)

25. Ivanova M. G. Idnakar: Drevneudmurtskoe gorodishche IX-XIII vV. (Idnakar: Ancient Udmurtian Settlement of IX-XIII Centuries) // Udmurt Institute of history, language and literature, Izhevsk, 1998. (In Russian).

26. Ivanova M. G. Srednevekovye gorodishcha Prikam'ya v kontekste processov gradoobrazovaniya (Medieval Settlements in the Kama Region in the Context of the Processes of the Creation of Cities) // Materialy i issledovaniya po srednevekovoj arheologii Vostochnoj Evropy. Kazan': Shkola, 2009. P. 119-125. (In Russian).

27. Ivanova M. G., Zav'yalov V. I. Drevneudmurtskie kuznecy (Ancient Udmurtian Smiths) // Vestnik of the Russian humanitarian scientific Fund. 2001. No. 1. P. 7-14. (In Russian).

28. Ilovajskij D. I. Razyskaniya o nachale Rusi (Researches about Beginning of Rus). Moscow: Grachev and $C^{\circ}, 1876$ 466 p. (In Russian).

29. Kazakov E. P. Kul'tura rannej Volzhskoj Bolgarii (The Culture of Early Volga Bulgaria). Moscow, Nauka, 1992, 335 p (In Russian).

30. Kazakov E. P. Hronologicheskie ehtapy vzaimodejstviya sarmat s povolzhskimi finnami v srednie veka (Chronological Stages of the Interaction of Sarmats with the Volga Finns in the Middle Ages) // Vestnik of the Kazan State University of Culture and Arts. 2015. No. 4-2. (In Russian).

31. Kalinina T. M. Drevnyaya Rus' i strany Vostoka v X v. (Srednevekovye arabo-persidskie istochniki o Rusi) (Ancient Russia and the Oriental Countries in X Century. (The Medieval Arab-Persian Sources about Russia): thesis. Moscow, 1976. (In Russian).

32. Kalinin N. F., Halikov A. H. Itogi arheologicheskih rabot za 1945-1952 gg. (The Results of the Archeological Works in 1945-1952) // Works of the Kazan branch of the Academy of Sciences of the USSR. Kazan', 1954. P. 61-63. (In Russian).

33. Karasik A. M. K voprosu o tret'em centre Rusi (On the Third Center of Rus) // Istoricheskie zapiski. 1950, v. 35. P. 304305. (In Russian).

34. Karsanov A. N. K voprosu o trekh gruppah rusov (On the Three Groups of the Ruses) // Germenevtika drevnerusskoj literatury X-XVI vv. Moscow: The Institute of world literature of Russian Academy of Sciences, 1992. Sb.3. P. 5-13. (In Russian).

35. Kirpichnikov A. N. Velikij volzhskij put' i ladozhsko-volhovskij sever Rusi v ehpohu rannego srednevekov'ya (Great Volga Way and Ladoga-Volkhov North of Rus in the Early Middle Ages) // Ladoga i Ladozhskaya zemlya v ehpohu srednevekov'ya. Issue.1. St. Petersburg: Nestor-Istoriya, 2006. (In Russian).

36. Kokovcov P. K. Evrejsko-hazarskaya perepiska $\vee$ X v. (Jewish-Khazar Correspondence in X c.). Leningrad: Academy of Sciences of the USSR, 1932. (In Russian).

37. Konovalova I. G. Rasskaz o trekh gruppah rusov v sochineniyah arabskih avtorov XII-XIV vv. (The Story of Three Groups of the Ruses in the Works of Arab Authors of the XII-XIV Centuries) // Drevnejshie gosudarstva Vostochnoj Evropy. 1992-1993. Moscow, 1995. P. 139-148. (In Russian). 
38. Konovalova I. G. Toponim kak sposob osvoeniya prostranstva («Russkaya reka» al-ldrisi) (Placename as a Way of Mastering Space ("Russian river" of al-Idrisi) // Dialog so vremenem: Al'manah intellektual'noj istorii. Moscow, 2001, Issue. 6. P. 192-219. (In Russian).

39. Korzuhina G. F. Put' Abu-Hamida al-Garnati iz Bolgara v Vengriyu (Abu Hamid al-Garnati's Route from Bolgar to Hungary) // Problemy arheologii. Issue. II. Leningrad, 1978. (In Russian).

40. Korzuhina G. F. Russkie klady (Russian Treasures). Moscow: Academy of Sciences of the USSR, 1954. 226 p. (In Russian).

41. Korobejnikov A. V. Idnakar i analiz gorodishch s pozicij ih urovnya zashchity (Idnakar and Analysis of Settlements in Terms of Their Level of Protection) // Idnakar, 2008. No. 4. P. 38-63. (In Russian).

42. Kuz'min A. G. "Varyagii») i «Rus') na Baltijskom more ("Waragias" and "Rus" at the Baltic Sea) // Voprosy istorii. 1970.

No.10. P. 28-55. (In Russian).

43. Kuz'min A. G. Kreshchenie Kievskoj Rusi (The Baptism of Kievan Rus). Moscow: Algoritm, 2012. 272 p. (In Russian)

44. Kuz'min A. G. Nachalo Rusi (The Beginning of Rus). Moscow: Veche, 2003. 630 p. (In Russian).

45. Lovmyan'skij H. Rus' i normanny (Rus and the Normans). Moscow: Progress, 1985. 304 p. (In Russian).

46. Mavrodin V. V. Obrazovaniye Drevnerusskogo gosudarstva (The Formation of the Ancient Russian State). Leningrad Leningrad university, 1945. 432 p. (In Russian).

47. Makarov L. D. Drevnerusskoe naselenie Prikam'ya v X-XV vekah (Ancient Population of the Kama Region in the X-XV Centuries). Izhevsk: Udmurt state university, 2006. 143 p. (In Russian).

48. Materialy po istorii turkmen i Turkmenii (Materials on the History of the Turkmens and Turkmenia). Vol I. VII-XV vV. Arabskie i persidskie istochniki. Moscow-Leningrad: Academy of Sciences of the USSR, 1939.612 p. (In Russian).

49. Machinskij D. A. Rostovo-suzdal'skaya Rus' v X v. i «tri gruppy Rusi» vostochnyh avtorov (Rostov-Suzdal Rus in the $X$ Century and "Three Groups of Rus" of Eastern Authors) // Materialy k ehtnicheskoj istorii Evropejskogo Severo-Vostoka. Syktyvkar: Perm' university, 1985. P. 3-23. (In Russian).

50. Minorskij V. F. Istoriya Shirvana i Derbenda v X-XI vekah (History of Shirvan and Derbend in X-XI Centuries). Moscow: Oriental literature, 1963. 270 p. (In Russian).

51. Mongajt A. L. K voprosu o trekh centrah Drevnej Rusi (On the Three Centers of Ancient Rus) // Brief information of the Institute of the History of Material Culture, 1947. (In Russian).

52. Mongajt A. L. Ryazanskaya zemlya (In Ryazan Land). Moscow: Academy of sciences of the USSR, 1961. 400 p. (In Russian).

53. Nasonov A. N. Tmutarakan' v istorii Vostochnoj Evropy (Tmutarakan in the History of Eastern Europe) // Istoricheskie zapiski. Vol. 6. 1940. P. 79-99. (In Russian).

54. Novosel'cev A. P. Vostochnye istochniki o vostochnyh slavyanah i Rusi VI-IX vv. (Eastern Sources about Eastern Slavs and Rus of VI-IX Centuries) // Drevnerusskoe gosudarstvo i ego mezhdunarodnoe znachenie. Moscow: Nauka, 1965. P. 355-419. (In Russian).

55. Parhomenko V. A. Nachalo hristianstva Rusi (The Beginnings of Christianity in Rus). Poltava: Printing house of G. I. Markevich, 1913. 191 p. (In Russian).

56. Parhomenko V. A. Tri centra drevnejshej Rusi (Three Centers of Ancient Rus) // Izvestiya Otdeleniya russkogo yazyka i slovesnosti. Vol. XVIII. Book. 2. St. Petersburg, 1913. P. 79-87. (In Russian).

57. Parhomenko V. A. U istokov russkoj gosudarstvennosti (The Origins of the Russian Statehood). Leningrad: Gosizdat, 1924. 116 p. (In Russian).

58. Petruhin V. Ya. Tri «centra» Rusi. Fol'klornye istoki i istoricheskaya tradiciya. (Three "centers" of Rus. Folklore Origins and Historical Tradition) // Hudozhestvennyj yazyk srednevekov'ya. Moscow: Nauka, 1982. P. 143-158. (In Russian).

59. Polnoe sobranie russkih letopisej (Full Collection of Russian Chronicles). Vol. I. Moscow: Yazyki russkoj kul'tury, 1997. 496 p. (In Russian).

60. Poluboyarinova M. D. Put' iz Bulgara v Kiev. Torgovye svyazi s Kievskoj Rus'yu i drevnerusskimi knyazhestvami. (Route from Bulgar to Kiev. Trade Relations with Kievan Rus and the Ancient Russian Principalities) // Istoriya tatar. Vol.II. Volzhskaya Bulgariya i Velikaya step'. Kazan', 2006. P. 316-326. (In Russian).

61. Puteshestvie Abu Hamida al-Garnati v Vostochnuyu i Central'nuyu Evropu (Travel Abu Hamid al-Garnati in Eastern and Central Europe). Moscow: Oriental literature, 1971.137 p. (In Russian).

62. Rybakov B. A. Kievskaya Rus' i russkie knyazhestva XII-XIII vv. (Kievan Rus and the Russian Principalities XII-XIII Centuries). Moscow: Nauka, 1982. 592 p. (In Russian).

63. Rybakov B. A. Put' iz Bulgara v Kiev (Route from Bolgar to Kiev) // Drevnosti Vostochnoj Evropy. 1969. No.169. P.186196. (In Russian).

64. Savel'ev P. S. Muhammedanskaya numizmatika $v$ otnoshenii $\mathrm{k}$ russkoj istorii (Muhammedanische Numismatics in Relation to Russian History). St. Petersburg, 1846. 180 p. (In Russian).

65. Sedov V. V. Drevnerusskaya narodnost' (The Ancient Russian Nationality). Moscow: Yazyki russkoj kul'tury Publ, 1999. 317 p. (In Russian).

66. Sedov V. V. Slavyane. Istoriko-arheologicheskoe issledovanie (Slavs. Historical-archaeological Research). Moscow: Yazyki slavyanskoj kul'tury, 2002. 624 p. (In Russian).

67. Smirnov P. P. Volz'kij shlyah i starodavni Rusi (Volga Route and the Ancient Ruses). Kiiv, 1928. 228 p. (In Russian).

68. Smokotina D. V. Arsa: mesto na karte (Arsa: a Place on the Map) // Vestnik of Tomsk state university. History. 2008 No. 2. P. 5-17. (In Russian).

69. Smokotina D. V. Baltijsko-Kaspijskij torgovyj put'v ehpohu rannego srednevekov'ya (The Baltic-Caspian Trading Route in the Early Middle Ages). Tomsk, 2012. 24 p. (In Russian).

70. Sobolevskij A. I. "Tret'e» russkoe plemya (The "Third" Russian Tribe) // Reports of Academy of sciences of the USSR 1920. No. 4. P. 55-58. (In Russian). 
71. Stepanenko V. P. K istorii srednevekovoj Tavriki (On the History of Medieval Taurica) // Vizantiya i srednevekovyj Krym. Issue. 26. Barnaul, 1992. P. 125. (In Russian).

72. Studencov A. F. Tajna proiskhozhdeniya Drevnej Rusi (The Mystery of the Origin of Ancient Russia). Rostov on Don: St. Petersburg: Feniks, 2006. 285 p. (In Russian).

73. Toporov V. N. Evrejskij ehlement v Kievskoj Rusi (The Jewish Element in Kievan Rus) // Slavyane i ih sosedi. Moscow, 1993. P. 28-42. (In Russian).

74. Toporov V. N. Ob iranskom ehlemente v russkoj duhovnoj kul'ture (On the Iranian Element in the Russian Spiritual Culture) // Slavyane i ih sosedi. Moscow, 1993. (In Russian).

75. Toporov V. N. Rabotniki odinnadcatogo chasa. «Slovo o zakone i blagodati) i drevnerusskaya real'nost' (Workers of the Eleventh Hour. "A Word about Law and Grace" and the Ancient Russian Reality). Russian literature, 1988, Vol. XXIV. (In Russian)

76. Toporov V. N. Svyatost' i svyatye v russkoj duhovnoj kul'ture (Holiness and Saints in Russian Spiritual Culture). Vol. I. Moscow: Yazyki russkoj kul'tury, 1995, 875 p. (In Russian).

77. Fomin O. Svyashchennaya Artaniya (Sacred Artania). Moscow: Veche, 2005. 432 p. (In Russian)

78. Hennig R. Nevedomye zemli (Unknown Lands). Vol. II. Moscow: Foreign literature, 1961.520 p. (In Russian)

79. Shakhmatov A. A. Drevneyshiye sudby russkogo plemeni (Ancient Fates of the Russian Tribe). Prague, 1919. (In Russian).

80. Shcheglov D. F. Pervyye stranitsy russkoy istorii (The First Pages of Russian History) // Zhurnal Ministerstva narodnogo prosveshcheniya. 1876. (In Russian).

81. Yushkov S. V. K voprosu o proiskhozhdenii Russkogo gosudarstva (On the Origin of the Russian State) // Scientific notes of Moscow state juristic university. Moscow, 1940. Issue. IV. P. 37-59. (In Russian).

82. Frähn C. M. Ibn Foszlan's und anderer Araber Berichte uber die Russen alterer Zeit. Saint-Petersburg, 1828.

83. Hudud al-'Alam: "The Regions of the World". London, 1937.

84. Hrbek J. Der dritte Stamm der Rus nach arabischen Quellen. Archiv Orientalni. Praha, 1957. T. 25.

85. Lewicki T. Swiat slowianski w oczach pisarzy arabskich. Slavia Antiqua. Poznań, 1949/1950. T. II. s. 373.

86. Mouradja d'Ohsson A.C. Des peuples du Caucase et du Nord de la Mer Noire dans le 10 siecle. Paris, 1828

87. Reinaud M. Geographie d'Aboulteda. I. Introduction generale a la geographie des Orientaux. Paris, 1848.

88. Vernadsky G. The Origins of Russia. Oxford. At the Clarendon Press. 1959. $354 \mathrm{p}$.

89. Wilinbachow W.B. Przyczynek do zagadnienia trzech osrodkow dawnej Rusi // Materyaly Zachodnio-Pomorskie. Szczecin, 1961. T. VII. S. 517-530. 